\title{
THE ROBIN HOOD LEGEND AND ITS CULTURAL ADAPTATION FOR THE FILM INDUSTRY: COMPARING LITERARY SOURCES WITH FILMIC REPRESENTATIONS
}

\author{
Richard Clouet \\ Universidad de \\ Las Palmas de Gran Canaria
}

\begin{abstract}
The legend of Robin Hood has been going strong for over 600 years. In that time, the English hero has been a medieval revolutionary, an earl in Renaissance drama, a Saxon freedom fighter in the XVIIIth and XIXth centuries or a courteous robber. Nowadays the hero is especially known as a famous romantic film star. This paper is about the way the legendary hero has been interpreted over the centuries and the medieval texts translated and adapted to suit the taste of the new audience. This capacity of adaptation in the Robin Hood legend has been demonstrated in the twentieth century through the various film adapatations of the now legitimate bandit, rightfully fighting against coercive and unjust authorities.
\end{abstract}

"In the early 1990s the Hollywood movie, Robin Hood - Prince of Thieves, captured the hearts and minds of millions, its phenomenal success reflecting a timeless fascination with the world's most famous outlaw"(Phillips and Keatman 1995: 1). With such words, G. Phillips and M. Keatman started their bestselling Robin Hood - The Man Behind the Myth, an amazing thesis on the popular myth written in the way detective stories are. Robin Hood is certainly the most famous outlaw of them all, as popular today as when the stories first appeared over six hundred years ago. But let us make clear, right from the beginning of this paper, that Robin Hood never existed (Clouet 1998: 51). Many historians, like M. Keen or R.H. Hilton, agree on the fact that the figure of Robin Hood was just a creation of the ballad muse. 
There is no doubt that the early Robin Hood ballads are medieval: a sign of their popularity is that they are already mentioned in Piers Plowman, in the last quarter of the fourteenth century and in the Chronicle of Scotland in 1420. Of the thirty-eight Robin Hood ballads printed by Francis James Child (185759), three are widely considered the earliest in date: Robin Hood and the Monk (Child 119), Robin Hood and the Potter (Child 121), and A Gest of Robyn Hode (Child 117). The first two survive in manuscripts dated c. 1450 and c. 1500 respectively, while the Gest exists only in five printed texts and fragments of the sixteenth century, the two earliest versions being those of Jan Van Doesborch of Antwerp around 1510 and Wynkyn de Worde around the same time or earlier. There is ambiguity about both the date of composition of the Gest and the whole issue of dating is complicated by the fact that the work is constructed or compiled from pre-existing materials. Hence, when we talk about the date of composition, we are referring to the time when the poet compiled the various sources and constructed the long narrative with its interlocking episodes. But what has particularly drawn our attention for this paper is the lack of consensus about the historical time depicted. The only true allusion embedded in the text to its historical context is that of the name of the monarch: "Edwarde, our comly kynge". Attempts to identify the specific monarch have frustrated scholars, such as Maurice Keen, who laments that "If any of the names could be identified, it would make the task simpler." He proceeds to survey briefly the various candidates: "Edward III, who reigned from 1327 to 1377 , would seem to fill the part best; but both the warrior King Edward I, who died in 1307, and Edward IV, who came to the throne in 1461 and was known in his day as the handsomest monarch of Europe, could just fit" (Keen 1961: 143)

Not all scholars agreed with Maurice Keen. Some preferred Richard the Lionheart or Henry III and, very recently, Thomas H. Ohlgren and Stephen Knight demonstrated that "Edwarde, our comly kynge" could only be Edward III (Ohlgren and Knight 1997: 32). Scholarly uncertainty persists, even if most historians agree that the background is either a late thirteenth- or fourteenthcentury one, since it would have been very difficult to keep the oral tradition alive for such a long period of time before the ballads were recorded and printed.

The film industry, however, has preferred the end of the twelfth century for the setting of the plot. This is probably the result of the influence of Sir Walter Scott's Ivanhoe. Following Joseph Ritson's image of Robin Hood as a man of the people, the superman of his age, fighting for truth, justice and the English way of life, Sir Walter Scott and the nineteenth-century novelists of the Gothic revival paved the way for the cinematographic tradition of the twentieth century. The hero now stood for the oppressed Anglo-Saxon struggling against the Norman oppressor. In placing Locksley in Richard the 
Lionheart's reign, Scott simply followed Major's assumption (1892) enshrined in Ritson's Life (1795) that Robin Hood was a genuine twelfth-century Englishman. Moreover, the fact that Robin robbed the rich to give to the poor was now clearly enunciated. This romantic illustration of Christian charity is not so obvious in the early ballads. The author of the Gest did give some social objectives to his hero in the opening stanzas. Little John asks Robin who they shall rob, and Robin answers as follows:

\author{
'Thereof no force,' than sayde Robyn; \\ We shall do well inowe; \\ But loke ye do no husbonde harme \\ That tylleth with his ploughe. \\ 'No more ye shall no gode yeman \\ That walketh by grene wode shawe; \\ Ne no knyght ne no squyer \\ That wol be a gode felawe.' (Dobson and Taylor 1989: 80)
}

The protagonist tells his outlaw mates not to harm yeomen or husbandmen, not even honest knights, like the one he helps in the ballads, Sir Richard at the Lee. However, in later ballads, Robin Hood no longer helps the poor. He would rather rob them and beat them up. The romantic motif will only be revived in the nineteenth century and later taken up by the film industry.

Another striking feature of A Gest of Robyn Hode is the incongruity between Robin's social class -yeomanry- and his repeated display of knightly customs and etiquette, such as offering liveries and fees to newly recruited gang members; granting a boon to the wife of the bankrupt knight; not eating until an "unkouth gest" arrives; and hand-washing before meals. Once again, the film versions avoided this ambiguity and did not maintain Robin Hood's position in the social hierarchy as defined by the early ballads. The films have preferred the figure of Robin Hood as a nobleman, probably because it goes much better with the romantic idea of the hero: he becomes either (Sir) Robert of Locksley or (Sir) Robin Hood, fourth earl of Huntington. This change in his lineage can be traced to two Elizabethan plays, written towards the end of the sixteenth century, in which "Robert, Earl of Huntington, being outlawed, takes refuge in Sherwood, with his chaste love Mathilda, daughter of Lord Fitzwaters, and changes his name to Robin Hood, hers to Maid Marian" (Child 1957: 45).

The potency of the legend on the screen is revealed by a fantastic statistic : twenty-four major Robin Hood films were made in the twentieth century. The first three silent British films were Robin Hood and bis Merry Men (1908) in which Robin rescued a man from the gallows; Robin Hood Outlawed (1912) in which Robin rescued Maid Marian from the clutches of an evil knight, 
and Days of Robin Hood (1913) in which Robin disguised himself as a monk to rescue one of his men from the Sheriff of Nottingham. On the American continent, the first two silent films were Robin Hood (1912), in which the plot revolves around Sir Guy of Gisborne and Robin vying for Maid Marian's favour, and Robin Hood (1913) in which Robin wins an archery contest and helps Alan a Dale rescue his sweetheart. Those early films showed a strong relationship to Victorian stage melodrama and romanticism and did not focus on a single ballad source. What is clear, though, is that the number of early films indicates the potential that was seen in the story by film-makers from the very beginning.

The first major success in the genre is undoubtedly the 1922 Robin Hood, starring Douglas Fairbanks Senior, and the screenplay of which Fairbanks himself (under the pseudonym of Elton Thomas) helped to write. The film opens with a jousting tournament in which Robin, as the Earl of Huntingdon, takes part and falls for Maid Marian. The knights depart on crusade while Prince John begins a reign of tyranny. Marian sends word to Huntingdon via his squire Little John. Robin forms an outlaw band in Sherwood Forest, rescues Maid Marian with the help of a mysterious knight who turns out to be King Richard. The latter pardons Robin and re-unites him with Marian.

Another great success in the Robin Hood cinematography was The Adventures of Robin Hood (1938), directed by Michael Curtis and William Keighly, starring Errol Flynn as Robin Hood, Olivia de Havilland as the beautiful Maid Marian, Basil Rathbone as a supercilious Sir Guy of Gisborne, Claud Rains as evil Prince John and Alan Hale as a large Little John. This film version of Robin Hood, regarded as the best by fans and critics alike, became one of Warner Bros Studios greatest hits. The film was seen as a definitive portrait of the Robin Hood legend and Errol Flynn as a definitive Robin Hood by many filmgoers. Varying little from the usual story involving King Richard, Maid Marian, Prince John, Sir Guy of Gisborne and the Sheriff of Nottingham, the film excelled in its swashbuckling action scenes.

In that 1938 version, Robin Hood is represented as Sir Robert of Locksley, fourth earl of Huntingdon. Although the reason why he is an outlaw is not clearly explained in the early ballads, in the film his persistent defiance of authority is the cause of his becoming an outlaw: he defies Prince John, entering a Norman banquet with a deer which has been poached -poaching was considered a crime in that age- and also accuses the powerful prince of plotting against his brother Richard. As we have seen before, there are some peculiarities in the film adaptations which did not exist in the medieval ballads, such as the political issue of the Saxon/Norman rivalry, or the love story between Robin and Marian. In the 1938 version, just as in most films of Robin Hood, the hero is fighting the intruder and defending the interests of the rightful king. 
The 1940s, 1950s and 1960s were characterized by a great proliferation of Robin Hood films. We could just mention The Bandit of Sherwood Forest (1946) in which a first-class fencer, Cornel Wilde, played Robin's son with plenty of energy; Prince of Thieves (1948), the leading role of this version, based on a tale by Alexandre Dumas, being played by Jon Hall; Rogues of Sherwood Forest (1950) in which Robin's son again appeared, this time played by Jon Derek, and in which Alan Hale played Little John for the third time; Tales of Robin Hood (1951), which was actually a failed American television pilot episode produced by Hal Roach, had the usual storyline of archery contest, forest battle and Robin saving Maid Marian; The Story of Robin Hood and His Merry Men (1952), the first Disney venture into the greenwood with Richard Todd as Robin; Son of Robin Hood (1959), surprisingly starring June Laverick as the daughter of Robin Hood; Men of Sherwood Forest (1960), starring Don Taylor; Sword of Sherwood Forest (1961) with Richard Greene and A Challenge for Robin Hood (1967) with Barrie Ingham, Peter Blythe and James Arnatt. Most were modest Robin Hood films.

One important production consisted of the successful TV stories known as The Adventures of Robin Hood (1956-1960) and still remembered with great affection. It had several re-runs selling to many countries throughout the world. Richard Greene, a Hollywood star, brought athletic good looks and style to the role, in which he and his men were forever foiling the plans of the dastardly Sheriff played by Alan Wheatley. The now extremely famous theme tune that concluded each episode went as follows: "Robin Hood, Robin Hood, riding through the glen / Robin Hood, Robin Hood, with his band of men / Feared by the bad, loved by the good, / Robin Hood, Robin Hood, Robin Hood."

The 1970s saw the production of three movies and a cartoon. Wolf's Head: The Adventures of Robin Hood (1973) starred David Warbeck and depicted the outlaws as gritty, dirty men, fighting to stay alive. This realistic rendering of the legend was not too popular. The same year, the Disney animated feature, Robin Hood, a box-office hit, was released. In this famous cartoon, directed by Wolgang Reitherman, all the characters are played by animals - Robin (voiced by Brian Bedford) is a cunning fox, Little John (Phil Harris) is a bear and the bad guys (Peter Ustinov voiced Prince John) are vultures and rhinos. Finally, Robin and Marian (1976) turned out to be the first epic version of the story. In this film by Richard Lester, Sean Connery plays an older Robin and Audrey Hepburn an older Maid Marian, now a nun. A war weary Robin returns home from campaigning with King Richard (Richard Harris) with trusted friend Little John (a very funny Nicol Nicholson) after the King is mortally wounded. He finds the people are still oppressed under the rule of Prince John and the Sheriff of Nottingham (Robert Shaw). Robin faces a final challenge against arch-enemy Sheriff of Nottingham and rekindles his romance with Maid 
Marian. The final scene is a weepie where Robin, badly wounded, shoots an arrow out of the window and, as in the Gest, he tells Little John to bury him where it lay.

The most recent Robin Hood versions are four films from the mid-1980s and early 1990s. In Robin of Sherwood (1984), the Hooded Man is portrayed by Michael Praed. Robin, a poor yeoman of Loxley village, has two new friends: Nasir who, like Little John, first fights Robin then joins him; and Herne the Hunter, Robin's mystical mentor akin to King Arthur's Merlin, who gives him a new longbow and protective sword called Albion. The mixing of traditional ballads with magic and sorcery brought the film a cult following. In 1991, John Irwin directed a new version, Robin Hood, choosing Patrick Bergin as the hero. It is a darker version of the legend in which Robin is a flawed hero. Will Scarlett shows all the compassion and Uma Thurman plays a bratty, independent Maid Marian. The plot is less about injustice than Normans versus Saxons and is an attempt to move away from legend into modern-style realism. Also in 1991, Robin Hood: Prince of Thieves, directed by Kevin Reynolds, had a greater success. Robin, played by a very American Kevin Costner, returns home from the Crusades with Azim, a Moor friend, played by Morgan Freeman, to find his people under siege from the cruelties of the Sheriff of Nottingham, played by Alan Rickman. The action, adventure and romance are thrilling with plenty of original action - Robin shoots two arrows simultaneously from his bow in two directions. Marian, played by Mary Elizabeth Mastrantonio, is a convincing damsel in distress and Friar Tuck is played by Michael McShane. It also includes the cameo performance of Sean Connery as King Richard.

The last production, but not the least one, is Mel Brooks' Robin Hood: Men in Tights (1993), a parody of the numerous Robin Hood movies we have presented so far. The film spoofed the Kevin Costner version in particular. Robin returns from the Crusades to discover that his castle is gone, and all that is left is a blind servant. Robin succeeds in uniting a band of peasants, and then proceeds to battle corruption, save the country, and win the heart of Maid Marian.

Comparing the early legend with the film adaptations is a minutious task that would require much more time and space. What stands out, though, is that three major aspects contributed to the changes and prepared the ground for the twentieth-century film productions: the May Games (in the fifteenth century), Sir Walter Scott's Ivanhoe (1819) and Alexandre Dumas's two novels Robin Hood, prince des voleurs (1872) and Robin Hood le proscrit (1873), both translated in 1903 as Robin Hood: Prince of Thieves and Robin Hood the Outlaw.

In the course of the fifteenth century Robin Hood was adopted in the May Games, the old traditional celebration of the spring festival. Consequently the 
tales broadened and diversified according to the means of communication and the audience. The content of the story was also affected: new characters were introduced, new elements were included and new tales were concocted. The association of Robin and Maid Marian, now present in all fims, goes back to such festivals and draws on a single literary source, the French pastoral play Robin and Marion, composed c.1283 by Adam de la Halle, in which the shepherdess Marion, loyal to her lover Robin, successfully resists the advances of a knight.

Later, in 1819, Sir Walter Scott, in his famous Ivanboe, foisted a new role on Robin Hood, one that was going to stick to his character for the following two centuries. Robin now stood for the oppressed Anglo-Saxon struggling against the Norman oppressor. There was absolutely nothing to support this historical element but Scott simply followed the traditional chronology originating with Major and enshrined in Ritson's biography and added his own romantic inspiration. He also clearly stated the fact that Robin robbed the rich and gave to the poor.

At the end of the nineteenth century, Alexandre Dumas the Elder produced two major novels in the Robin Hood tradition: Robin Hood, prince des voleurs (1872) and Robin Hood le proscrit (1873), in which the emphasis was put on how Robin formed his band and rescued Maid Marian from a knight with evil intentions, a situation that was much used in the cinema. Dumas also drew a lot on epic settings with splendid scenes, exciting battles, thrilling chases, etc, giving new material to twentieth-century film-makers.

All three sources contributed to the emergence of a difference of characterization between the films and the early ballads. We mentioned before the fact that, although a yeoman in the early texts, he is represented as a romantic nobleman in the films, following the tradition of the XIXth-century versions of the story in which the hero is usually a destitute baron robbing the rich to give to the poor. Another particular feature that differentiates the Robin Hood ballads and the films is the religious character of the hero. The Gest deals with Robin's devotion towards the Virgin, and therefore, due to this pious love, he respects all women. We cannot find this religious aspect of his personality in any of the films, this being probably due to the fact that the advent of Protestantism in England displaced the cult of the Virgin Mary: in John Irwin's version starring Patrick Bergin, it is even the opposite case, if we consider the fact that he robs the Church and threatens the bishop in order to obtain more money for his men. Still, both in the ballads and the films, Robin is a courteous outlaw. His courtesy in his behaviour towards women, his good temper, and his manliness have always contributed to the survival of his legend. Both in the Gest and in the film, he also shows an absolute loyalty to his king, the interest of whom he always defends. 
Definitely, Robin Hood had become a fit topic for the screen, both for adults and children. However, whatever a new generation makes of a tale, something of the older appreciation of it is likely to survive. The processes of change affected the traditional meaning of the legend (cf. the May Games, Scott and Dumas) but its enduring success is a clear sign that some key structures remained viable. In our opinion, the two major motifs that remained largely impervious to historical change are that of outlawry and the forest. The concept of outlawry and the greenwood were more important than the historical and social reality, the centrality of Robin's outlaw status and inhabitation of the forest being embodied in his relationship to the sheriff and to his own followers. These two motifs, present in all the films we have mentioned, have contributed to capture the hearts and minds of millions of people, men and women, children and grown-ups. Both outlawry and the forest are part of what Jeffrey L. Singman calls the "ludic format" of the legend (Singman 1998: 166), thus allowing the creation of any number of episodic stories from the matrix of the medieval legend. As such, the structure can easily change to meet the needs of the audience.

This capacity of adaptation in the Robin Hood legend has been demonstrated in the twentieth century through the various film adapatations and, more recently, in Kevin Reynolds's Robin Hood: Prince of Thieves, with the enhanced role accorded to Maid Marian in response to changing gender relations, and the introduction of a non-European character into Robin Hood's band of outlaws to reflect the multicultural realities of the modern world. The basic scenario is the same, but as the world the Robin Hood legend represents is more remote than ever to the public, the audience can no longer interact with the same immediacy, whether as consumers or producers, and Robin Hood can no longer carry the same sociopolitical significance he enjoyed in the early period. The oppressed Anglo-Saxon struggling against the Norman oppressor has now become the legitimate outlaw fighting for equity and justice.

ROBIN HOOD FILMS (in alphabetical order)

Adventures of Robin Hood. Dir. Michael Curtiz. With Errol Flynn, Basil Rathbone and Olivia De Havilland. Warner Bros,1938.

Adventures of Robin Hood. Dir. Bernard Knowles, Lindsay Anderson, Ralph Smart, Terry Bishop. With Richard Greene. CBS, 1955-1958. (143 episodes.)

Bandits of Sherwood Forest. Dir. George Sherman and Henry Levin. With Cornel Wilde and Anita Louise. Columbia, 1947.

A Challenge for Robin Hood. Dir. C.M. Pennington-Richards. With Barrie Ingham and James Hayter. Seven Arts-Hammer, 1967. (British; distributed in U.S. by Fox.) 
Long Live Robin Hood. Dir. George Ferron. With Mark Damon and Louis Davilla. Edde Entertainment, 1993.

Men of Sherwood Forest. Dir. Val Guest. With Don Taylor and Eileen Moore. Astor, 1954.

The Prince of Thieves. Dir. Philip Ford. With Monte Hall. Republic, 1949.

Robin and Marian. Dir. Richard Lester. With Sean Connery and Audrey Hepburn. Columbia Studios, 1976.

Robin and the Seven Hoods. Dir. Gordon Douglas. With Frank Sinatra, Dean Martin, and Bing Crosby. Warner Bros., 1964.

Robin Hood. Dir. Theodore Marston. Mutual Film Corp., 1913. (Silent.)

Robin Hood. Dir. Allan Dwan. With Douglas Fairbanks and Wallace Beery. United Artists, 1922.

Robin Hood. Dir. Wolfgang Reitherman. Disney, 1973. (Animated.)

Robin Hood. Dir. John Irvin. With Patrick Bergin and Uma Thurman. Fox, 1991.

Robin Hood and the Pirates. Dir. Giorgio Simoneli. With Lex Barker. (Italy, 1961.) (Dubbed.)

Robin Hood Jr. Dir. Frankie Lee. Export \& Import Film Co., Inc., 1923. (Silent.)

Robin Hood Jr. Dir. Matt McCarthy. With Keith Chegwin and Mandy Tulloch. Brocket, 1975. (British.)

Robin Hood of Monterey. Dir. Christy Cabanne. With Gilbert Roland. Monogram Pictures Corp., 1947.

Robin Hood: Prince of Thieves. Dir. Kevin Reynolds. With Kevin Costner, Morgan Freeman and Mary-Elizabeth Mastrantonio. Morgan Creek Productions, Inc., 1991.

Robin Hood and the Sorcerer. Dir. Ian Sharp. Goldcrest Films and Television Productions, 1983.

Rogues of Sherwood Forest. Dir. Gordon Douglas. With John Derek and Diana Lynn. Columbia, 1950.

The Story of Robin Hood. Dir. Richard Todd and Joan Rice. RKO- Disney, 1952. (British title: The Story of Robin Hood and His Merrie Men.)

Son of Robin Hood. Dir. George Sherman. With David Hedison and June Laverick. Argo, 1958. (British)

Sword of Sherwood Forest. Dir. Terence Fisher. With Richard Greene and Peter Cushing. Hammer Film Productions, 1960. (British; distributed in the U.S. by Columbia.)

Tales of Robin Hood. Dir. James Tinling. With Robert Clarke and Mary Hatcher. Lippert Pictures, 1951.

The Zany Adventures of Robin Hood. Dir. Ray Austin. With George Segal, Morgan Fairchild, and Roddy McDowall. Bobka Production/Fries Entertainment, 1988. 


\section{REFERENCES}

Phillips, G. \& M. Keatman. 1995. Robin Hood-The Man Behind the Myth. London: Michael O'Mara Books Limited.

Child, F. J. 1957. The English and Scottish Popular Ballads. New York: The Folklore Press.

Clouet, R. 1998. Robin-des-Bois: le hors-la-loi lègitime des ballades mèdièvales. Lilles: Editions du Septentrion.

Dobson, R. B. \& J. Taylor. 1989. Rymes of Robyn Hood: An Introduction to the English Outlaw. Gloucester: Alan Sutton.

Keen, M. 1961. The Outlaws of Medieval Legend. London: Routledge \& Kegan Paul.

Hilton, R. H. 1976. Peasants, Knights and Heretics: Studies in Medieval English Social History. Cambridge: Cambridge University Press.

Knight, S. 1994. Robin Hood: A Complete Study of the English Outlaw. Oxford: Blackwell.

Ohlgren, T. and Knight, S. 1997. Robin Hood and Other Outlaw Tales. Kalamazoo, Michigan: Medieval Institute Publications.

Ritson, J. 1795. Robin Hood: A Collection of all the Ancient Poems, Songs and Ballads Now Extant Relative to the Celebrated English Outlaw (To Which are Prefixed Historical Anecdotes of His Life). London: Egerton and Johnson.

Singman, J. L. 1998. Robin Hood, the Shaping of the Legend. London: Greenwood Press. 